\title{
The Little Engine That Could - How to Start the Motor? Motivating the Online Student
}

\author{
Kay Dennis, EdD \\ Assistant Professor of Adult Education \\ Park University \\ Lisa Bunkowski, PhD \\ Assistant Professor of History \\ Park University \\ Micheal Eskey, PhD \\ Assistant Professor of Criminal Justice \\ Park University
}

Motivation is a function of initiating and sustaining goal-directed action. In addition to individual variables, student motivation is influenced by situational variables that include course design, instructional approach, and to a great extent, faculty behavior. This article presents classic literature on motivation and offers a grounded set of instructional methods and strategies with which faculty can spark and sustain motivation that leads to deep rather than superficial learning in the online learner. These classic motivational techniques have a direct relationship with today's online learner. The authors highlight the significance of external influences and describe some of the many opportunities available to faculty to enhance the motivation of online students to learn.

\section{Introduction}

With the growth of distance learning and changes in family working roles, the typical student profile has shifted from the "traditional" 18-22 year-old full-time undergraduate student residing on campus toward the employed, older college student who struggles to balance education with job and family (Allen and Seaman, 2006). Allen and Seaman suggest that online students tend to be older, work fulltime or hold additional employment, and have more outside and family responsibilities when compared to the more traditional student. Valued rewards vary according to personal goals. This paper examines how faculty in colleges and universities can motivate and meet the needs of online adult learners and thereby play a critical role in improved rates of completion of continuing higher education.

Any analysis of student achievement, in order to guide strategies for improvement, must include an examination of what drives behavior - motivation. Why is motivation so important for learning success? It is the "key to persistence and to learning that lasts. The challenge is to help each person clarify his or her important purposes and then to find, or create, the combination of educational experiences that lead to those desired outcomes" (Chickering and Kuh, 2005, p. 1).

Student motivation both typically and

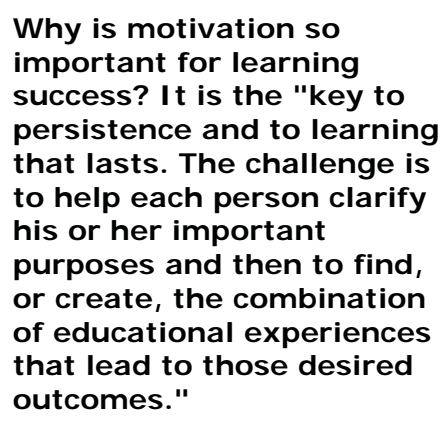
academic activities (Lumsden, 1994). Greater initiative, tenacity, and self-discipline are needed to take courses in the online environment than in the traditional classroom (Mandernach, et al., 2006). A student who is intrinsically motivated undertakes an activity "for its own sake, for the enjoyment it provides, the learning 
it permits, or the feelings of accomplishment it evokes" (Lepper, 1988, p. 290). Conversely, an extrinsically motivated student performs and strives to succeed "in order to obtain some reward or avoid some punishment external to the activity itself," such as grades or teacher approval (Lepper, 1988, p. 290). For example, some students are motivated more by the goal of the degree than the education; some may be motivated by the promotion that follows the degree; still others by the prestige in the eyes of their family and friends. Although students may be equally motivated to perform a task, the sources of their motivation may differ. As instructors we must find these differences and, subsequently, the differing motivators. We must determine if they are intrinsically or extrinsically motivated, or a combination thereof. In this article the authors explore motivation to learn, and propose specific approaches for online faculty interested in strengthening their students' motivation to learn.

\section{Goal Orientation}

Motivation derives from a variety of forces. It is dynamic, highly subject to change, and a major factor in readiness and desire to learn (Cashin, 1979). Students choose to exert a specific type and level of effort, and their reasons are as diverse as their attitudes and abilities. As these authors have discovered, students may be equally motivated to perform a task, yet the sources of their motivation may differ. Online instructors must recognize, monitor, and attempt to influence those factors that motivate students.

A number of factors are important to online students. They want independence; however, they also want and value timely faculty

Motivation derives from a variety of forces. It is dynamic, highly subject to change, and a major factor in readiness and desire to learn. interaction (Northrup, 2002). It is important, beneficial, and useful for online instructors to make their classroom settings as "real" and live for the student, through strategies such as "hands-on" empirical research assignments, using student mentors, including oral communications (telephone, video, MP3, two-way synchronous chats, etc.), and working with local practitioners to coordinate student internships (Mandernach, et al., 2006).

Among the motivation-related concepts examined was achievement goal orientation (Dweck, 1986). Dweck proposed that students who possess intrinsic (or mastery) orientation long for new skills and knowledge. They find satisfaction in the innate rewards of learning. This attitude guides their achievement behavior, which emphasizes contextualized learning. Intrinsically or mastery oriented students engage with the content, their peers, and faculty, netting a longer retention span and a greater ability to use what they learn. Such students are independent, lifelong learners (Chasteuneuf, 2006).

In contrast, students with extrinsic (or performance) orientation concern themselves with achievement chiefly in relation to their peers (Vansteenkiste and Lens, 2006). They use rote memorization and study for immediate gain according to what they expect to see on a test. These behaviors may be observed in students enrolled in introductory-level courses or general education requirements. Such learning carries a brief life expectancy and is superficial (Ames, 1990). In the experience of these authors, extrinsically motivated students are seeking benefits such as grades, positive feedback or other indicators of teacher approval. Many such students openly disclose the incentives that motivate their efforts, such as maintaining a grade average to preserve financial aid, fulfilling degree requirements, improving career prospects, or winning the approval of significant others.

\section{Metacognition}

Motivated students direct their learning very deliberately. After goal orientation, another factor associated with motivation and learning success involves 
self-regulating and monitoring strategies, known collectively as metacognition (Flavell, 1979). Students possessing metacognitive skills and habits are aware of their cognitive processing methods and employ study behaviors appropriate to the situation. Hallmarks of metacognition include a heightened awareness of one's thinking, selection of processing strategies from a repertoire, reflection and readjustment, and sustained motivation to achieve (Paris and Winograd, 2004).

\section{Self-Efficacy}

Another individual variable relates to perception of one's ability to learn subject matter successfully. Self-efficacy, as described by Bandura (1986), refers to one's sense of ability to succeed at a given task to a specified level. Self-efficacy is a task-specific quality; a student may be a talented and confident pianist (and therefore enjoy a sense of self-efficacy at piano-playing), yet be painfully aware of low achievement in a history class (and will feel inefficacious there as a result). Students who perceive themselves as limited in capability lack the confidence, energy and motivation that successful study efforts bring. Their achievement behavior is limited. They regulate themselves away from attempting a rigorous academic effort because, based on experience, they do not "see" it happening (Ames, 1990).

\section{Situational Variables}

While some would suggest that a student's goal orientation, and by extension the student's motivation, affects response to individual or situational variables, Chasteauneuf (2006) countered that the real issue is how those internal and external variables inform a student's choice of goal orientation. This is a powerful thought, since external factors such as social forces clearly affect motivation (Bandura, 1971). Situational variables take many forms. Motivation in most students is socially mediated, affected by influences including classroom dynamics. Consider the effects of sarcastic or deprecating comments following a student's erroneous statement - which sometimes occurs in the classroom. When it happens in the online environment, the authors believe its effects can be especially damaging because peer replies are visible onscreen for weeks to come. The hapless student who spoke in error cannot soothe his embarrassment with hopes the gaffe will be forgotten; it is in full view of everyone. He or she is unlikely to volunteer another statement soon.

According to Ames (1992), motivational considerations include various cues found in the course, such as learning expectations stated in the syllabus or by the instructor. Students utilize these cues to form impressions of the value or importance of a learning task, assignment, or the course as a whole. For example, students may respond to an assignment by deciding that it is of little consequence, so they decide not to exert their best effort. In such a case superficial learning may not be followed by deeper consideration of the topic. Students gauge the difficulty of the course and assess its value for their needs and purposes. In a course that fosters commitment and motivation to learn, students can thrive.

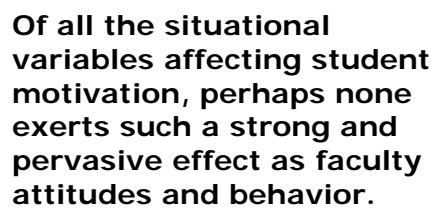

\section{Faculty Behavior}

Of all the situational variables affecting student motivation, perhaps none exerts such a strong and pervasive effect as faculty attitudes and behavior. Instructional communication such as giving feedback on performance constitutes a prime opportunity either to enhance motivation or decimate it. Receiving feedback or a grade on performance creates a high-stakes situation for students, for they take it very personally, and not only in the academic sense. Their self-esteem and 
self-efficacy are affected; they either find themselves on solid footing or in quicksand. Therefore, the manner in which feedback is delivered, particularly in the online environment, is of paramount importance.

Lacking the opportunity to provide the face-to-face immediacy found in the physical classroom, online instructors are challenged to find other means of closing the social and psychological distance between themselves and their students (Arbaugh, 2001). Verbal interaction between instructors and students is vital. Instructors in online courses, more so than in face-to-face courses, must seek evidence of students' feelings and motivation, especially their reactions to the written word, which is devoid of vocal tone. This interaction can be fostered by using students' names in discussion posts, sharing personal anecdotes related to course concepts, and encouraging students to respond to instructor questions as well as to comments made by their peers (Hutchins,

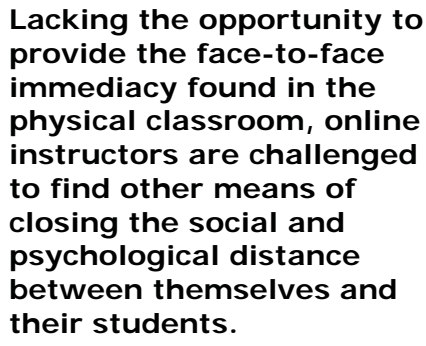

2003). Working with peers reduces learner anxiety and is an effective method of increasing the motivation of online students (Moore, 2006). The more effort online instructors put into closing that social and psychological gap in their class discussions using appropriate immediacy behaviors, the greater the reward in student interaction (Arbaugh, 2001).

In order to improve performance and at the same time sustain desire to learn, feedback is best delivered respectfully, tactfully and constructively, so as to save face. Face refers to the positive self-image students hope to internalize and preserve through interactions with others. If face is threatened, a student may withdraw from interaction and engagement with assigned tasks. Consequently, the level of motivation declines. On the other hand, faculty guidance, recognition and approbation yield an increase in student motivation to exert greater effort (KerssenGriep, 2003).

Additional strategies to enhance motivation include guiding students toward their own discoveries of facts and relationships. Self-esteem grows when students realize success in acquiring, storing, and retrieving key information (Alutu, 2006). They accomplish this through thoughtful questioning and being encouraged to construct knowledge that is personally meaningful and durable over time. Further evidence of the impact of instructor interventions on goal and learning orientation, motivation, achievement and retention of online adult learners was established by Chyung (2000), who determined that the motivational attraction of online instruction for adult learners related to perceptions of the learning climate, learning outcomes, and improved retention of students.

\section{Data Collection}

Effective teaching, support and motivation involve faculty research. What works, and what does not? An optimal way to determine what instructors do to support and motivate their students is to observe them and ask them. The authors formally collected data on over 200 online adjunct instructors during AY2006-2007. Their observation illuminated a number of key areas: what works; what does not work; what students like; what students do not like; student complaints vs. student praise; stimulating discussions vs. dead spots (Bunkowski, et al., 2006).

This examination of more than 200 online adjunct faculty and courses enabled the authors to identify five key dimensions of effectiveness: Interaction, individual attention, timeliness of information and response, information transmission, and accessibility and skill at moderating the flow of learning. These were viewed and assessed through bi-weekly assessments of online student-student and faculty-student interaction in the classroom. 


\section{Success Formula}

Based on their research, the authors have compiled a "short list" of key elements for consideration by faculty wishing to improve their effectiveness in motivating online students (Bunkowski, et al., 2006):

Whenever possible, course topics should be current (for every discipline). A textbook will never be as current as today's primary news medium, the Internet. Excellent resources include CNN (http://www.cnn.com/), Fox (http://www.foxnews.com/), CBS (http://www.cbsnews.com/), and BBC (http://news.bbc.co.uk/). Information from these sources can be integrated in a course and revised as necessary. Students are increasingly savvy and enjoy discussing current events in the city, state, county, region, nation, or world with their classmates.

A wealth of information is available to students. In gathering

Whenever possible, course topics should be current (for every discipline). A textbook will never be as current as today's primary news medium, the I nternet.

appropriate material for online discussions, faculty can dispense some of the responsibility to the students. A semi-structured approach allows students some latitude while ensuring they address the course objectives. These authors have discovered that students generally rise to the challenge of exchanging information, directing questions, and seeking clarification at a surprisingly sophisticated level.

The online discussion forum is not a place for domination. The key is keeping students on their toes through moderation. Occasional refereeing may be necessary as a last resort. Motivation to learn occurs at strategic intervals, beginning prior to start of term. Faculty have opportunities to spark student interest as course syllabi are posted to the course platform.

Figure 1 divides a course into specific points at which suggested motivational strategies can be used with success. More detailed information on ways to engage learners can be found in Appendix A, where The Nine Events of Instruction (Gagne, 1985) are provided along with comments from these authors. Appendix $B$ explains the use of " $\mathrm{R}_{2} \mathrm{~A}_{2}$ "; and Appendix $C$ offers an actual case study illustration of faculty-facilitated metacognition.

\section{Connection between Faculty and Student Motivation}

A critical component of student motivation and the success of the online learning experience is the motivation of the instructor. Student performance, according to Crumpacker, is "contingent on instructor skill and level of effort of motivation" (2001, p.1). The factors that influence faculty motivation include positive factors or incentives, and negative factors or obstacles. Recent studies of online faculty reveal the following motivating incentives for online instruction (McKenzie et al., 2000):

- Flexible working conditions

- Enjoyment of on-line instruction

- Enhanced technological skills

- Interaction with a diverse student population

- Increased job satisfaction

- $\quad$ Ease of updating and revising courses

- Ability to ensure that course topics are relevant

Financial considerations such monetary awards do not appear to be a significant motivating factor (Rockwell et al., 2000). Release time and reductions in faculty workloads are reported to be more desirable than financial rewards - at least to senior faculty (Rockwell et al., 1999). 
Figure 1: Strategic Steps for Successful Students

\begin{tabular}{|c|c|c|c|c|c|}
\hline Pre-term wk. & Day 1 of Term & $\begin{array}{l}\text { End of } \\
\text { Week } 1\end{array}$ & Weekly & At Midterm & Final Week \\
\hline $\begin{array}{l}\text { Post syllabus } \\
\text { and specific } \\
\text { "success" tips } \\
\text { Post } \\
\text { photograph } \\
\text { and a friendly } \\
\text { introduction } \\
\text { Ask students } \\
\text { to post photos } \\
\text { and } \\
\text { introductions } \\
\text { Incorporate } \\
\text { some choice } \\
\text { on class topics } \\
\text { and } \\
\text { assignments } \\
\text { Verify effective } \\
\text { use of section } \\
\text { headings, } \\
\text { color, text, } \\
\text { intuitive flow } \\
\text { of course } \\
\text { Create a } \\
\text { thread to post } \\
\text { weekly } \\
\text { Teacher's Tips } \\
\& \text { Tricks and } \\
\text { invite student } \\
\text { sharing of } \\
\text { their best tips } \\
\text { Create a } \\
\text { virtual lounge- } \\
\text { students only } \\
\text { Ask students } \\
\text { to assess their } \\
\text { learning skills } \\
\text { and areas for } \\
\text { improvement }\end{array}$ & $\begin{array}{l}\text { Vividly describe } \\
\text { course's value } \\
\text { in } \\
\text { real-life context } \\
\text { Log in 2-3 } \\
\text { times; be } \\
\text { responsive and } \\
\text { genuinely } \\
\text { enthusiastic } \\
\text { Guide students' } \\
\text { reading (look } \\
\text { for } \\
\text { this...compare...) } \\
\text { Summarize self- } \\
\text { assessments \& } \\
\text { improvement } \\
\text { goals; urge } \\
\text { peer support to } \\
\text { aid all students } \\
\text { Post "primer" on } \\
\text { metacognition \& } \\
\text { model it in a } \\
\text { discussion post } \\
\text { Ensure an early } \\
\text { success for } \\
\text { each student; } \\
\text { praise and } \\
\text { document it } \\
\text { Recognize every } \\
\text { student in some } \\
\text { manner } \\
\text { diversity factors } \\
\text { motivation } \\
\text { Decide to reduce } \\
\text { "mental miles" } \\
\text { between faculty } \\
\text { and students } \\
\text { Internalize } \\
\text { caring \& show } \\
\text { sincere interest } \\
\text { in course and } \\
\text { all students } \\
\text { Consider } \\
\text { altural, }\end{array}$ & $\begin{array}{l}\text { Urge formation } \\
\text { of peer learning } \\
\text { support pairs } \\
\text { Introduce peer } \\
\text { critiques of } \\
\text { thinking/writing } \\
\text { Demonstrate \& } \\
\text { promote deep } \\
\text { versus } \\
\text { superficial } \\
\text { thinking } \\
\text { Stress belief in } \\
\text { students' ability } \\
\text { to succeed and } \\
\text { grow via course } \\
\text { Create context } \\
\text { Introduce } \mathrm{R}_{2} \mathrm{~A}_{2} \\
\text { Recognize } \\
\text { Relate } \\
\text { Assimilate } \\
\text { Apply (Hill, } \\
1960 \text { ) } \\
\text { See Appendix B } \\
\text { Summarize and } \\
\text { connect the } \\
\text { core course } \\
\text { elements } \\
\text { Clarify course } \\
\text { expectations, } \\
\text { performance, } \\
\text { and grading } \\
\text { Ask students } \\
\text { for their best } \\
\text { effort: to } \\
\text { benefit them } \\
\text { Question to } \\
\text { self: What } \\
\text { effect am * } * * \\
\text { having upon } \\
\text { my students' } \\
\text { motivation to } \\
\text { learn? }\end{array}$ & $\begin{array}{l}\text { Aid discovery } \\
\text { via good } \\
\text { questioning } \\
\text { Encourage links } \\
\text { among course, } \\
\text { life } \\
\text { experiences, } \\
\text { current events } \\
\text { Illustrate type } \\
\text { of performance } \\
\text { expected } \\
\text { Model \& discuss } \\
\text { expert thinking } \\
\& \text { processing } \\
\text { Praise, } \\
\text { reinforce } \\
\text { quality efforts } \\
\text { Give feedback } \\
\text { to } \\
\text { each student } \\
1: 1 \\
\text { Correct } \\
\text { privately and } \\
\text { respectfully } \\
\text { In group } \\
\text { setting, affirm } \\
\text { everyone - } \\
\text { sincerely } \\
\text { Re-assess the } \\
\text { nature and } \\
\text { ways of your } \\
\text { thinking } \\
\end{array}$ & $\begin{array}{l}\text { Schedule time } \\
\text { for reflection on } \\
\text { subject and on } \\
\text { learning } \\
\text { successes \& } \\
\text { challenges } \\
\text { Plan efforts \& } \\
\text { focus for rest of } \\
\text { term } \\
\text { Devise a plan } \\
\text { to motivate self } \\
\text { for balance of } \\
\text { course } \\
\text { Continue using } \\
\text { psychological } \\
\text { lens to view } \\
\text { each student's } \\
\text { attitude, effort } \\
\& \text { performance } \\
\& \text { adjust yours } \\
\text { accordingly } \\
\text { WHAT ELSE } \\
\text { CAN } \\
\text { YOU THINK OF? }\end{array}$ & $\begin{array}{l}\text { Summarize \& } \\
\text { reinforce } \\
\text { CLOs* within } \\
\text { context of the } \\
\text { major, global } \\
\text { society, etc. } \\
\text { Emphasize the } \\
\text { value of overt } \\
\text { learning for } \\
\text { academic \& } \\
\text { career success } \\
\text { Encourage all } \\
\text { students to } \\
\text { extend insights } \\
\text { by constantly } \\
\text { re-framing the } \\
\text { subject matter } \\
\text { Urge students } \\
\text { to explore the } \\
\text { more complex } \\
\text { issues \& their } \\
\text { implications on } \\
\text { broader scale } \\
\text { Reflect, record } \\
\text { lessons } \\
\text { learned while } \\
\text { teaching this } \\
\text { course, for } \\
\text { future use } \\
\text { HOW CAN YOU } \\
\text { USE THESE } \\
\text { EXPERIENCES } \\
\text { TO IMPROVE } \\
\text { YOUR OWN } \\
\text { TEACHING \& } \\
\text { LEARNING? } \\
\text { * CLOs = } \\
\text { Core Learning } \\
\text { Outcomes }\end{array}$ \\
\hline
\end{tabular}

According to McKenzie et al. (2000), the major obstacles interfering with instructor motivation include:

- $\quad$ Decreased live, face-to-face interaction with students

- Lack of time to plan and deliver an on-line course

- Lack of support \& assistance

- $\quad$ Burden of training time to learn $\&$ update technology skills

- Inadequate compensation \& incentives

- Heavier workload

- Slow computer access 
Deubel (2003, p. 1) argues that "an instructor's attitude, motivation, and true commitment toward instruction delivery via distance education programs" have a direct bearing on the quality of online instruction. To optimize faculty motivation and thereby enhance student learning and foster student motivation, one must maximize the incentives and minimize the obstacles. As instructors move from the traditional classroom to the online learning environment, their roles change from "teacher" to "facilitator, mentor and coach" (Yang and Cornelious, 2005, p. 216), or "learning catalyst" (Volery and Lord, 2000, p. 4).

The following suggestions can help to support online faculty as they make this transition, and to sustain their satisfaction and high level of motivation (Crumpacker, 2001; Deubel, 2003; Rockwell et al., 2000; McKenzie et al., 2000; Rockwell et al., 1999; Yang and Cornelious, 2005):

- Training with emphasis on:

o Online pedagogy

o Adult learning theory

o Technology skills

o Course facilitation

o Institutional Policies \& procedures

- Communication with administration

- Peer mentoring

- Evaluation of instructors \& courses

- Ongoing training in course delivery/management system

- Professional development opportunities

- Ongoing technical support

- Manageable class sizes

- Reward system (Priority course assignment, stipend awards, release time, etc.)

Motivated instructors are better able to guide and motivate students as they assume a more active role as online learners. Students are more likely to have a positive learning experience with instructors who hold a positive attitude about teaching online (Yang and Cornelious, 2005; Volery and Lord, 2000).

\section{Conclusion}

As we shift from an institution of face-to-face student-instructor interaction to online instruction it is increasingly important that we dedicate the needed time and resources to programs that address the unique challenges of online students. It is important that we embrace the factors that motivate our students, predict the success of our students and reflect the practices of successful online instructors in online teaching.

From this research, we may both gather and add to the best practices employed by instructors in the motivation of online students. As indicated by the observations of the authors within the context of this study

As we shift from an institution of face-to-face student-instructor interaction to online instruction it is increasingly important that we dedicate the needed time and resources to programs that address the unique challenges of online students. and through faculty evaluations and observations, a clear distinction exists between the needs of in-class versus online students. Further, the motivators of online students include, but certainly are not limited to, timely course material, information sharing between faculty and students, and mediation and moderation by involved instructors. Each of these factors involves dedicated and motivated instructor interaction which, in turn, affects student motivation. The current research points to a need for ongoing and further research in the area of motivating our growing population of online students. 


\section{References}

Alutu, A. N. G. (2006). The guidance role of the instructor in the teaching and learning process. Journal of Instructional Psychology, 65, 44-49.

Ames, C. A. (1990). Motivation: What teachers need to know. Teachers College Record, 91(3), 409-421.

Ames, C. A. (1992). Classrooms: Goals, structures, and student motivation. Journal of Educational Psychology, 84, 261-271.

Arbaugh, J. B. (2001). How instructor immediacy behaviors affect student satisfaction and learning in webbased courses. Business Communication Quarterly. 65, 42-54. http://web.ebscohost.com.pegleg.par k.edu/ehost/detail vid $=4 \&$ hid $=103 \&$ s id=26e6da6f-573c-406c-bd9a1b46c48ff953\% 40sessionmgr104 bib4up\#bib4up

Bandura, A. (1986). Social foundations of thought and action: $A$ social cognitive theory. Englewood Cliffs, NJ: Prentice-Hall.

Bunkowski, L. M., Eskey, M. T. \& Gonzales, R. (2006). Ensuring academic quality: innovations in faculty mentorship and evaluation. Sloan-C Conference. Orlando, FL.

Cashin, W. E. (1979). Motivating students. Idea Paper No. 1. Kansas State University: Division of Continuing Education Center for Faculty Evaluation \& Development.

Chasteneuneuf, C. (2006). Motivation and text-based learning. American Educational Research Association Annual Meeting. San Francisco, CA.

Chickering, A. W., \& Kuh, G. D. (2005). Promoting student success: Creating conditions so every student can learn (Occasional Paper No. 3). Bloomington, Indiana: Indiana University Center for Postsecondary Research.
Chyung, Y. (2001). Systemic and systematic approaches to reducing attrition rates in online higher education. American Journal of Distance Education, 15, 36-49.

Crumpacker, N., (2001). Faculty pedagogical approach, skill, and motivation in today's distance education milieu. Online Journal of Distance Learning Administration 4:4. Retrieved April 1, 2007, from http://www.westga.edu/\% 7Edistance Lojdla/winter44/crumpacker44.html

Deubel, P. (2003). Learning from reflections - Issues in building quality online courses. Online Journal of Distance Learning Administration, 6. Retrieved April 1, 2007, from http://www. westga.edu/ distance/oj dla/fall63/deubel63.htm

Diaz, D. P. (2002). Online drop rates revisited. The Technology Source, May - June. Retrieved J une 3, 2003, from http://technologysource.org/article/o nline_drop_rates_revisited/

Dweck, C. S. (1986). Motivational processes affecting learning. American Psychologist, 41, 10401048.

Flavell, J. H. (1979). Metacognition and cognitive monitoring: a new area of cognitive developmental inquiry. American Psychologist, 34, 906-911. http://web.ebscohost.com.pegleg.par k. edu/ehost/detail? vid $=4 \&$ hid $=103 \& \mathrm{~s}$ id=26e6da6f-573c-406c-bd9a1b46c48ff953\%40sessionmgr104 bib9up\#bib9up

Gagne, R. M. (1985). The conditions of learning and theory of Instruction. Orlando, FL: Harcourt Brace College Publishers. http://web.ebscohost.com.pegleg.par k.edu/ehost $/$ detail ? vid $=4 \&$ hid $=103 \& s$ $\mathrm{id}=26 \mathrm{e} 6 \mathrm{da6f}$-573c-406c-bd9a1b46c48ff953\%40sessionmgr104 bib10up\#bib10up 
Gagne, R, Brigg, L., \& Wager, W. (1992). Principles of Instructional Design ( $4^{\text {th }}$ ed). Boston, MA: Wadsworth Publishing.

Hill, N. (1937). Think and Grow Rich. New York: The Random House Publishing Company.

Hutchins, H. M. (2003). Instructional immediacy and the seven principles: Strategies for facilitating online courses. Online Journal of Distance Learning Administration, 6. Retrieved March 27, 2007, from http://www. westga.edu/ distance/oj dla/fall63/hutchins63.html

Kerssen-Griep, J., Hess, J. A., \& Trees, A. R. (2003). Sustaining the desire to learn: Dimensions of perceived instructional facework related to student involvement and motivation to learn. Western Journal of Communication, 67, 357-361.

Lepper, M. R. (1988). Motivational Considerations in the Study of Instruction. Cognition and Instruction, 5, 289-309.

Lumsden, L.S. (1994). Student motivation to learn (ERIC Digest No. 92). Eugene, OR: ERIC Clearinghouse on Educational Management.

Mandernach, B. J., Donnelli, E., \& Dailey-Hebert, A. (2006). Learner attribute research juxtaposed with online instructor experience: Predictors of success in the accelerated, online classroom. Journal of Educators Online, 3(2).

McKenzie, B. K., Mims, N., Bennett, E. \& Waugh, M. (2000). Needs concerns and practices of online instructors. Online Journal of Distance Learning Administration, 1. Retrieved April 1, 2007, from http://www.westga.edu/ distance/oj dla/fall33/mckenzie33.html

Moore, J. C. (2006). Collaboration online: Sloan-C Resources. Journal of Asynchronous Learning Networks, 10 , 81-89.
Northrup, P.T. (2002). Online learners' preferences for interaction. The Quarterly Review of Distance Education, 3, 219-226.

Paris, S. G. \& Winograd, P. (2004). The role of self-regulated learning in contextual teaching: principles and practices for teacher preparation. U.S. Dept. of Education. Retrieved April 2, 2007, from http://www. ciera.org/library/archive/ 2001-04/0104parwin.htm

Rich, A. (1977). Claiming an education. In A. Kesselman, L. D. McNair, \& N. Schniedewind (Eds.), Women: Images \& Realities, a Multicultural Anthology. Boston: McGraw Hill.

Rockwell, K., Schauer, J., Fritz, S. M., \& Marx, D. B. (2000). Faculty education, assistance and support needed to deliver education via distance. Online Journal of Distance Learning Administration, 3. Retrieved March 28, 2007, from

http://www. westga.edu/ distance/ro ckwell32.html

Rockwell, S. K., Schauer, J., Fritz, S. M., \& Marx, D. B. (1999). Incentives and obstacles influencing higher education faculty and administrators to teach via distance. Online Journal of Distance Learning Administration, 2. Retrieved March 28, 2007, from http://www. westga.edu/ distance/ro ckwell24.html

Svinicki, M. (2005). Student goal orientation, motivation, and learning. IDEA Paper 41. Kansas State University: Division of Continuing Education Center for Faculty Evaluation \& Development.

Volery, T. \& Lord, D. (2000). Critical success factors in online education. The International Journal of Educational Management, 14, 216 223. 
Yang, Y. \& Cornelious, L. F. (2005). Preparing instructors for quality online instruction. Online Journal of Distance Learning Administration, 8. Retrieved 1 April, 2007, from http://www. westga.edu/ distance/oj dla/spring81/yang81.htm

Dennis is Chair of the Adult Education Graduate Program and an Online Instructor Evaluator in the College for Distance Learning at Park University. She received her EdD in Higher Education Administration from North Carolina State University, her MSN in Nursing Management from East Carolina University, and her BSN in Nursing from the University of Kentucky. She has taught at Eastern Kentucky University, East Carolina University, Boston University, and now at Park University. Her scholarly interests relate to the cross-cultural and faculty behavioral aspects of academic success of students.

Bunkowski is an assistant professor of history at Park University and is currently on half-time academic release as an online instructor evaluator and mentor for the College for Distance Learning. Bunkowski earned her PhD in history from the University of Kansas, an MA in history and a BA in Spanish, cum laude, from Emporia State University. She has taught for Park University since 2004. Her current areas of historical research include violence and vigilantism in the mid-19th Century American West, with an emphasis on class, race and ethnicity in the geographic region of Kansas, Oklahoma and Texas. She is actively engaged in developing strategies for building community in the online classroom, and improving online teaching and learning. Additionally, she is a course developer, and is involved in developing new programs for Park University's College for Distance Learning.

Eskey is currently an assistant professor of criminal justice at Park University. Additionally, he is a course developer and online instructor evaluator for the Park University College of Distance Learning. He earned his Ph.D. in Criminology from the Florida State University (1982), an M.A. in Criminal Justice from the University of Nebraska at Omaha (1977), an M.S. in Strategic Intelligence from the Joint Military Intelligence College (1994), and a B.S. in Criminal Justice from the University of Nebraska (1975). He has taught criminal justice courses at both the undergraduate and graduate levels. His current research includes the area of homeland security and the delivery of online instruction to the unique student audiences of both the criminal justice field and the military. 
Appendix A: Gagne's Nine Events of Instruction

\begin{tabular}{|c|c|}
\hline Instructional Event & Specific Action for Faculty \\
\hline Gain and control students' attention. & $\begin{array}{l}\text { Enthusiastically describe your own } \\
\text { interest in the course/topic and its } \\
\text { value to you. Motivation sparks } \\
\text { motivation. }\end{array}$ \\
\hline Inform students of expected outcomes. & Describe the journey about to begin. \\
\hline $\begin{array}{l}\text { Stimulate recall of relevant prerequisite } \\
\text { capabilities. }\end{array}$ & $\begin{array}{l}\text { Remind students of their previous } \\
\text { mastery of necessary verbal and } \\
\text { intellectual skills. }\end{array}$ \\
\hline $\begin{array}{l}\text { Present the stimuli for learning, according } \\
\text { to the kind of learning required. }\end{array}$ & $\begin{array}{l}\text { Introduce course material in an orderly } \\
\text { and well-organized fashion. }\end{array}$ \\
\hline Offer guidance for learning. & $\begin{array}{l}\text { Carefully constructed questions induce } \\
\text { discovery. Students practice using } \\
\text { concepts; solve problems, etc. }\end{array}$ \\
\hline Provide feedback. & $\begin{array}{l}\text { Prompt, frequent, specific feedback } \\
\text { during early stages is critical to } \\
\text { achievement, self-efficacy, and } \\
\text { motivation. Encourage and guide } \\
\text { students to provide their own feedback } \\
\text { - assess their own learning for } \\
\text { completeness and accuracy } \\
\text { (metacognition). }\end{array}$ \\
\hline Appraise performance. & $\begin{array}{l}\text { Provide multiple opportunities for } \\
\text { students to demonstrate and verify } \\
\text { achievement. This promotes retention, } \\
\text { self-efficacy, and enhances motivation. }\end{array}$ \\
\hline $\begin{array}{l}\text { Make provisions for transfer of } \\
\text { knowledge. }\end{array}$ & $\begin{array}{l}\text { Periodically ask students how they are } \\
\text { connecting what they are learning to } \\
\text { their own lives. Generalizability } \\
\text { promotes learning, motivation, etc. }\end{array}$ \\
\hline Insure retention. & $\begin{array}{l}\text { Assign practical learning tasks that } \\
\text { require recall and significant effort, etc. }\end{array}$ \\
\hline
\end{tabular}

Appendix $B: R_{2} \underline{A_{2}}$

\section{Recognize $\rightarrow$ Relate $\rightarrow$ Assimilate $\rightarrow$ Apply \\ $" \mathbf{R}_{\mathbf{2}} \mathbf{A}_{2}$ "}

Napoleon Hill, author of the highly acclaimed 1937 book, Think and Grow Rich, is credited with this phrase. Hill, an American, was referring to a systematic method by which a person could grow in wisdom and thereby become more successful in achieving his or her goals. Hill's powerful and practical words resonated with millions of Americans who were struggling against the Great Depression.

To apply $R_{2} A_{2}$ to teaching and learning in the online environment, an instructor might assign a learning activity such as a well-focused discussion forum. Students would be expected to identify connections among course material, posts by their peers and instructor, and their own contributions to the discussion. The first step is to recognize a concept as familiar, then to relate or connect that concept to 
another concept - perhaps a newly introduced idea, or even a foundational concept from previous course material.

Once the student has recognized and related the concepts, he or she is to assimilate or weave them into the context of the discussion, unit, and course. In so doing the student actually uses the material which embeds it further into memory.

As the new information becomes personalized knowledge it can be applied to present and future situations. In the online learning environment, such situations might include further discussion postings, online debates, case studies, or essays such as position papers. Each of these learning activities strengthens student engagement with the material, and thereby potentially enhances learning outcomes.

\section{Appendix C: Training in Metacognition - Case Study}

One method for enabling students to achieve metacognition that fosters the development of mastery orientation is to introduce readings and discussion designed to stimulate introspection about motivation and the learning process. As Svinicki (2005) indicates, two main areas of student motivation exist:

1. Extrinsic, performance oriented - externally driven; where students are motivated by grades, diplomas, career advancement, increased status, renewed financial aid, etc., which leads to more superficial learning with shorter retention.

2. Intrinsic, mastery oriented - internally driven; where students are motivated to learn purely for the sake of learning which leads to deeper learning with more enduring retention.

The two motivations can exist simultaneously (Svinicki, 2005). The goal for educators is to encourage students to place more emphasis on intrinsic learning.

To accomplish this in the instructor of an online Introduction to Women's Studies course requires the students to read Adrienne Rich's essay "Claiming an Education" during the first week of class (Rich 1977). Rich gets to the heart of student motivation. She encourages students to accept responsibility and become active participants in their learning. She tells students to take risks; to take courses that challenge them; to seek out criticism. "It means assuming your share of responsibility," she writes, "for what happens in the classroom." Overwhelmingly, Rich's essay is successful in conveying her message. The following excerpts from student reaction papers, quizzes, and discussion forum postings demonstrate how effective this assignment is in evoking student introspection:

Student A: Adrienne Rich states to think of yourself as claiming your education rather than receiving your education. I thought to myself, "Hey, I never thought of it that way."

Student B: If you're claiming your education you are always finding new ways to challenge yourself in school. You're also taking criticism, and using it to push yourself further. To receive an education is to be passive and not involved, not taking things serious at all including yourself.

Student C: To claim an education is to go to college knowing that you want to satisfy yourself and to receive an education is to go to college to satisfy someone else's desire for you.

Student D: "Claiming an Education" is about how women have the right to claim an education and not just receive one. I never really thought of the word "claim" in the context of getting an education before.

Student E: It is about taking responsibility toward ourselves. That means pushing yourself to the limits and learning all there is to be learned. Taking the harder classes and taking it all in. Not selling yourself short. 
Student F: Rich explains that in order for students to claim their education they need to "demand to be taken seriously" which includes seeking out criticism, recognizing that it is great when someone demands that you push yourself further and shows how much and how far you can go. All in all, receiving an education would be getting a normal education and not exploring, but claiming an education would be demanding and pursuing every aspect of education to its fullest.

[Retrieved from Introduction to Women's Studies, Lisa Bunkowski, Florida Community College Jacksonville, 2007. Students A, B, \& C, Spring session A; Students D, E, \& F, Spring session B ]. 